\title{
Effects of Pilates-Interventional Program on Calcaneus-Bone Density Parameters of Adult Women
}

\author{
Efectos de un Programa de Intervención de Pilates Sobre \\ Parámetros de Densidad Ósea en el Calcáneo de Mujeres Adultas
}

Milena Mikalacki*; Nebojsa Cokorilo*; Borislav Obradovic*; Ana Marijanac* \& Pedro Jesus Ruiz-Montero**

MIKALACKI, M.; COKORILO, N.; OBRADOVIC, B.; MARIJANAC, A. \& RUIZ-MONTERO, P. J. Effects of Pilatesinterventional program on calcaneus-bone density parameters of adult women. Int. J. Morphol., 33(4):1220-1224, 2015.

SUMMARY: Physical exercise has a positive influence on bone tissue and therefore, is recommended in order to prevent the bone mass loss during the aging process. Similarly, normally practice of exercise potentially prevents the incidence of osteoporosis and bone fractures in adult women. In order to evaluate the differences of a Pilates-Interventional Program on parameters of bone density (right and left calcaneus) for six months, a total of 22 women (48.18 \pm 9.59$)$ participated in the study. Bone mineral density (BMD) was estimated by the broadband ultrasonic attenuation (BUA) and the speed of sound signals (SOS), through "Sahara" sound device. The BUA showed significant difference in the right and the left leg (both, $\mathrm{P}<0.01$ ), the SOS of the right leg $(\mathrm{P}<0.05)$, whereas the BMD was not proved to be statistically significant at the end of the treatment. In conclusion, the bone mineral density by BUA increased, while the speed of sound of the right leg decreased. Thus, our findings might imply a better level of bone strength after a specific intervention focused on the Pilates method.

KEY WORDS: Physical exercise; Calcaneus; Broadband ultrasonic attenuation; Speed of sound signals.

\section{INTRODUCTION}

Age and loss of BMD have been studied for long time with multiple theories (Blanchet et al., 2013). Osteoporosis is a systemic skeletal disorder characterized by decrease of bone loss in aging process (Karlsson et al., 2001; Rasic \& Tasic, 2009) and micro architectural deterioration of bone tissue (Rasic \& Tasic). The peak (maximum) of bone mass is achieved between the ages of 30 and 35, when the speed of new bone formation and resorption is relatively small and quite similar (Babic, 2004). Osteoporosis can occur in both sexes, and the risk increases with age, especially in women due to reduced production of estrogen during menopause, when some women may lose up to $15 \%$ of the total bone mass (Kohrt et al., 2004) . Early detection of osteoporosis is the first step towards the successful prevention, treatment and rehabilitation. The golden standard in BMD measuring is the method of dual exposure to X -rays (DEXA), and one of the methods for measuring BMD, which is diagnosed by an ultrasound technique usually on the calcaneus of a nondominant foot, is the quantitative ultrasound osteodensitometry (QUS) (Lazic \& Spasojevic, 2012).
The calcaneus is the largest of the tarsal bones and carries the total of body weight (Schencke \& del Sol, 2010). Calcaneus injuries are reported by patients with high complications (Firoozabadi et al., 2013). Thus, it is necessary to treat the injuries of calcaneus such as open fractures with a main aim: maximize function and appropriate quality of life according to expectations for outcome (Beltran \& Collinge, 2012).

Physical exercise in youth and adolescence positively affects the bone mass increase (Bielemann et al., 2013), while training in adulthood may maintain the bone mass and mechanical competence (Ahola et al., 2009). Similarly, exercise potentially prevents illness such as osteoporosis and bone fractures in women (Ahola et al.) because of decrease of bone loss in aging process (Karlsson et al.; Rasic \& Tasic) and transformation of skeleton through increase of peak bone mineral density (Ahola et al.; Karlsson et al.; McKay et al., 2000). Therefore, physical exercise is recommended as an intervention strategy to promote the optimal bone density

\footnotetext{
* Faculty of Sport and Physical Education, University of Novi Sad, Novi Sad, Serbia.

** Department of Physical Education and Sport, Faculty of Sport Sciences, University of Granada, Granada, Spain.

The present study was funded by the Provincial Secretariat for Science and Technological Development in Novi Sad, and was entitled. "Impact of Physical Activity on the Risk Factors of the Working Population" (number: 114-451-2337/2011-01).
} 
during youth and to lower the speed of body mass loss in middle-aged and elderly adults (Martyn-St James \& Carroll, 2008; Karlsson, 2004). According with a correct bone health, the American College of Sport Medicine (ACSM) recommends a mixture of endurance and resistance activities for maintaining of bone mass in adult and elderly women (Kohrt et al.). Similar study with Finnish females population aged between 35-40 years, worked out for 6 months intensely, showed an increase in bone mass density under the influence of training, which correlates with 12 month changes of bone mass (Ahola et al.).

The purpose of the present study was to evaluate the differences in bone density of right and left calcaneus of a sample of adult females during six-months PilatesInterventional Program.

\section{MATERIAL AND METHOD}

Participants. The study analyzed a sample of 22 female participants (48.18 \pm 9.59$)$ who voluntarily participated in the present study. The inclusion criteria of participants in the present study were i) not to have acute or terminal illness. Men were excluded because of the amount was not representative of the total. Participants were informed of the purpose of the present study.

Measurements. A cross-sectional study was used to assess calcaneus BMD of female participants. Body weight was measured to $\pm 0.1 \mathrm{~kg}$ on an electronic scale (SECA, Hamburg, Germany) with participants wearing light indoor clothing and no shoes. Measurements were performed following the standardized techniques adopted by the International Society for the Advancement of Kinanthropometry (ISAK) (Ross \& Marfell-Jones, 1991). BMI was calculated through dividing body weight $(\mathrm{Kg})$ by the square of body height $(\mathrm{cm})$. The calcaneus BMD was measured by an ultrasound densitometry, i.e. the method of qualitative ultrasound by "Sahara" ultrasound bone densitometer (Hologic, Inc., MA, USA), using non-ionizing ultrasound for evaluating bone density: BUA left and right calcaneus $[\mathrm{dB} / \mathrm{MHz}]$ and $\mathrm{SOS}$ - left and right calcaneus $[\mathrm{m} / \mathrm{s}]$. Results acquired by this method are sufficiently correlated with other methods as well as other

Table I. Central and dispersion parameters of anthropometrical variables and body composition variables.

\begin{tabular}{lcccccc}
\hline $\mathbf{n = 2 2}$ & Mean & SD & Min & Max & SKEW & KURT \\
\hline Body Height $(\mathrm{cm})$ & 166.5 & 5.56 & 158.00 & 179.00 & 0.399 & -0.257 \\
Body Weight $(\mathrm{cm})$ & 62.22 & 6.23 & 46.00 & 74.00 & -0.333 & 1.210 \\
BMI $\left(\mathrm{Kg} / \mathrm{m}^{2}\right)$ & 22.46 & 2.17 & 18.43 & 25.71 & -0.227 & -1.011 \\
\hline
\end{tabular}

$\mathrm{SD}=$ Standard Deviation; MIN= Minimum; MAX= Maximum; SKEW= Skewness; KURT $=$ Kurtosis. localizations. BMD is expressed as grams of mineral per square centimetre $\left(\mathrm{g} / \mathrm{cm}^{2}\right)$ or per volume $\left(\mathrm{g} / \mathrm{cm}^{3}\right)$ and all participants had the peak of bone mass and different intensity of bone loss. All assessment was carried out under the supervision of trained technicians.

Combining the measured values SOS and BUA by an algorithm is possible to mathematical index which provide a 'quantitative ultrasound index' (QUS). Except for this index, evaluated BMD is calculated, with the reference value 0.577 .

Procedure. Data was collected twice. The present study was initiated in May 2011 with a pre-test and concluded in November 2011, performing a post-test (24 weeks). The interventional program had an $80 \%$ attendance rate during this period. The interventional program consisted of music-based aerobics and Pilates method,basic to intermediate level. The sessions included in this interventional program took place twice per week, and lasted 55-60 min per day-session, with an effective physical activity time of 45 minutes, in line with the requirements laid by the American College of Sports Medicine (2009). This study was approved by Ethical Committee of University of Novi Sad.

Statistical analyses. Normality of distribution was tested by means of the kolmogorov-Smirnov test. Clinical statistical methods were used for the calculations of the means and standard deviation (SD), minimal and maximum values of BUA, SOS and estimated BMD. In order to establish the differences in density of calcaneus and the speed of sound in the pre-post test, paired samples T-test was used for two dependent groups of participants. Data were analyzed using the SPSS statistical program (SPSS for Windows 19.0, Inc., Chicago, Illinois, USA). For all analyses, significance was accepted at $\mathrm{P}<0.05$.

\section{RESULTS}

Based on the values of central and dispersion statistic parameters, as well as parametric normality of data distribution line, it was established that data distribution of all applied variables in this research do not deviate statistically significantly from the normal distribution $(\mathrm{P}<0.01)$.

Table I shows descriptive parameters of anthropometric body composition variables: height, weight, and BMI value of participants. According to values of BMI the female participants belong to the group of normal-weight people. Tables II shows descriptive parameters for bone density variables BUA, SOS, est. BMD: mean, standard deviation (SD) pre-test/post-test 
and p-value. According to descriptive parameters, there was a noticeable increase in variable values of broadband ultrasound attenuation (BUA) of the right and left leg on the post-test.

The speed of sound (SOS) was decreased by the end of Pilates-interventional program in the right leg, and slightly increased in the left leg. There was an increase in the value of assessed bone density (Est. BMD) post-test.

BUA variable showed a statistically significant difference pre-test/post-test both in right and left leg (P $<0.01)$. Statistically significant difference was noticed in the SOS after the Pilates-interventional program in the right leg ( $P<0.05)$, without differences in the left leg. Estimated bone mineral density (Est. BMD) was not significantly different in the post-test assessment after the Pilates-interventional program neither in the left nor in the right leg.

Minimum and maximum value of BUA, SOS and Est. BMD are showed in Table III. Minimum and maximum values post-test are higher than values assessed pre-test.
BUA in both right and left calcaneus, whereas the difference in SOS of right calcaneus was significant.

Physical exercise carries an important role in maintaining normal structure and functional bone strength during the lifetime (Karlsson et al.); therefore the bone quality in later life correlates with the habit of physical activity practice from the past. Yanagimoto et al. (2000) used ultrasound densitometry as a technique for measuring bone density in determining the effect of walking on bone quality. The BUA values predict fracture risk in older women white females (Brooke-Wavell et al., 2008) and decrease with the aging process (Wehbe et al., 2003), but the higher level of BUA was noticed in people who made more steps a day, which contributed to the normal level of bone quality (Muir et al., 2013). Increasing the number of steps in daily activities by doing the simple everyday tasks, might prevent reduction of bone mineral density in postmenopausal women (Muir et al.), while walking itself as a unique exercise of intervention does not contribute to BMD in the lumbar region of spine although there were obvious positive effects on the upper part of the femur (Martyn-St James \& Carroll).

Table II. Paired simples T-Test (BUA, SOS, Est. BMD).

\begin{tabular}{lccc}
\hline & Pre-test & Post-test & $\boldsymbol{P}$ \\
\hline BUA_Right $(\mathrm{dB} / \mathrm{MHz})$ & $70.71 \pm 12.57$ & $78.75 \pm 11.01$ & 0.001 \\
BUA_Left $(\mathrm{dB} / \mathrm{MHz})$ & $71.35 \pm 12.62$ & $80.32 \pm 8.96$ & 0.001 \\
SOS_Right $(\mathrm{m} / \mathrm{s})$ & $1538.81 \pm 24.47$ & $1533.2 \pm 18.27$ & 0.027 \\
SOS_Left $(\mathrm{m} / \mathrm{s})$ & $1538.47 \pm 21.63$ & $1538.1 \pm 19.1$ & 0.88 \\
Est.BMD_Right $\left(\mathrm{g} / \mathrm{cm}^{2}\right)$ & $0.4858 \pm 0.09$ & $0.4914 \pm 0.07$ & 0.5 \\
Est.BMD_Left $\left(\mathrm{g} / \mathrm{cm}^{2}\right)$ & $0.4866 \pm 0.08$ & $0.5087 \pm 0.07$ & 0.06 \\
\hline
\end{tabular}

$\mathrm{BUA}=$ Broadband ultrasonic attenuation; $\mathrm{SOS}=$ Speed of sound signals; Est. BMD= Estimated Bone Mineral Density.

Table III. Minimal and maximum values of BUA, SOS, Est.BMD (pre-test/ post-test).

\begin{tabular}{lcc}
\hline & $\begin{array}{c}\text { Pre-test } \\
\text { (Min-Max) }\end{array}$ & $\begin{array}{c}\text { Post-test } \\
\text { (Min-Max) }\end{array}$ \\
\hline BUA_Right (dB/MHz) & $50.81-104.24$ & $61.43-105.83$ \\
BUA_Left (dB/MHz) & $48.91-92.68$ & $65.48-98.08$ \\
SOS_Right (m/s) & $1503.56-1605.40$ & $1501.97-1576.26$ \\
SOS_Left $(\mathrm{m} / \mathrm{s})$ & $1500.94-1587.95$ & $1505.32-1585.01$ \\
Est.BMD_Right $\left(\mathrm{g} / \mathrm{cm}^{2}\right)$ & $0.34-0.68$ & $0.37-0.66$ \\
Est.BMD_Left $\left(\mathrm{g} / \mathrm{cm}^{2}\right)$ & $0.33-0.63$ & $0.41-0.65$
\end{tabular}

$\mathrm{BUA}=$ Broadband ultrasonic attenuation; $\mathrm{SOS}=$ Speed of sound signals; Est. $\mathrm{BMD}=$ Estimated Bone Mineral Density; Min= minimum; Max= Maximum.
High intensity of exercise improves the bone density in lumbar region of spine, proximal part of femur and density of calcaneus, measured by the quantitative ultrasound, among people who performed physical exercise and those who did not practice regular exercise (Vainionpää et al., 2005). According to Chahal et al. (2014), the responsible exercise of change in the value of broadband ultrasound attenuation of calcaneus of middle-aged women, should reach the high threshold of intensity and high frequency range. In addition, may have beneficial effect on muscle strength and bone density in middle-aged women. Our findings follow the same results and conclusion of Chahal's study with the unique difference that we use Pilate's method as main content of session.

Pilates workout includes strength and flexibility exercises, and according to research the influence of strength training on bone status

\section{DISCUSSION}

The aim of the present study was to evaluate the differences in bone density parameter of right and left calcaneus of an adult females sample during six-months Pilates-Interventional Program. The main results show better is still to be examined, considering the fact that three out of four studies which showed significant effect of strength training to bones were randomized studies, compared to four out of eight previous studies which were neutral or negative (Singh et al., 2009). The same author confirmed through results that 9-month- strength training did not modify the BMD of premenopausal women to the whole body or regional parts of the body. 


\section{CONCLUSION}

In conclusion, our findings showed that the bone density of the participants did not change either, but the value of the broadband ultrasonic attenuation (BUA) increased, and the speed of sound of the right leg decreased, which implies a better level of bone strength.

\section{ACKNOWLEDGMENTS}

A special thanks to all females who participated in this study, and to any inconvenience it may have caused them.

MIKALACKI, M.; COKORILO, N.; OBRADOVIC, B.; MARIJANAC, A. \& RUIZ-MONTERO, P. J. Efectos de un programa de intervención de pilates sobre parámetros de densidad ósea en el calcáneo de mujeres adultas. Int. J. Morphol., 33(4):1220-1224, 2015.

RESUMEN: El ejercicio físico tiene una influencia positiva en el tejido óseo y por consiguiente, es recomendado a la hora de prevenir pérdida de masa ósea durante el envejecimiento. Igualmente, la práctica regular de ejercicio previene la osteoporosis y fractura de huesos en población adulta y mayor. Con el fin de evaluar las diferencias de parámetros en la densidad ósea (huesos calcáneos derecho e izquierdo) tras un programa de intervención Pilates de 6 meses, un total de 22 mujeres $(48,18 \pm 9,59)$ participaron en el estudio. La densidad mineral ósea (DMO) fue estimada mediante la atenuación ultrasónica de banda ancha (AUBA) y la velocidad de las señales del sonido (VSS) a través del dispositivo de sonido "Sahara". La AUBA mostró diferencias significativas en ambos calcáneos $(\mathrm{P}<0,01)$, la VSS obtuvo diferencias significativas en el calcáneo derecho $(\mathrm{P}<0,5)$ y la DMO no mostró significancia alguna tras el programa de intervención. En conclusión, el calcáneo incrementó mediante medición AUBA mientras que VSS fue significativo en el calcáneo derecho. Nuestros resultados podrían implicar un mejor nivel de fuerza del calcáneo después de una intervención específica con Pilates.

PALABRAS CLAVE: Ejercicio físico; Calcáneo; Atenuación ultrasónica de banda ancha; Velocidad de las señales del sonido.

\section{REFERENCES}

Ahola, R.; Korpelainen, R.; Vainionpää, A.; Leppäluoto, J. \& Jämsä, T. Time-course of exercise and its association with 12-month bone changes. BMC Musculoskelet. Disord., 10:138, 2009.
American College of Sports Medicine. ACSM's Guidelines for Exercise Testing and Prescription. 8th ed. Philadelphia, Lippincott Williams and Wilkins, 2009.

Babic, L. Kalcijum, fosfor i metabolizam kosti, kalcijum regulisuci hormoni. U: Patoloska fiziologija. Novi Sad, Medicinski fakultet i Futura, 2004.

Beltran, M. J. \& Collinge, C. A. Outcomes of high-grade open calcaneus fractures managed with open reduction via the medial wound and percutaneous screw fixation. J. Orthop. Trauma, 26(11):662-70, 2012.

Bielemann, R. M.; Martinez-Mesa, J. \& Gigante, D. P. Physical activity during life course and bone mass: a systematic review of methods and findings from cohort studies with young adults. BMC Musculoskelet. Disord., 14:77, 2013.

Blanchet, C.; Giguère, Y.; Prud'homme, D.; Turcot-Lemay, L.; Dumont, M.; Leduc, G.; Côte, S.; Laflamme, N.; Rousseau, F. \& Dodin, S. Leisure physical activity is associated with quantitative ultrasound measurements independently of bone mineral density in postmenopausal women. Calcif. Tissue Int., 73(4):339-49, 2013.

Brooke-Wavell, K.; Khan, A. S.; Taylor, R. \& Masud, T. Lower calcaneal bone mineral density and broadband ultrasonic attenuation, but not speed of sound, in South Asian than white European women. Ann. Hum. Biol., 35(4):386-93, 2008.

Chahal, L.; Lee, R. \& Luo, J. Loading dose of physical activity is related to muscle strength and bone density in middleaged women. Bone, 67:41-5, 2014.

Firoozabadi, R.; Kramer, P. A. \& Benirschke, S. K. Plantar medial wounds associated with calcaneal fractures. Foot Ankle Int., 34(7):941-8, 2013.

Karlsson, M. Has exercise an antifracture efficacy in women? Scand. J. Med. Sci. Sports, 14(1):2-15, 2004.

Karlsson, M. K.; Magnusson, H.; Karlsson, C. \& Seeman, E. The duration of exercise as a regulator of bone mass. Bone, 28(1):128-32, 2001.

Kohrt, W. M.; Bloomfield, S. A.; Little, K. D.; Nelson, M. E. \& Yingling, V. R. American College of Sports Medicine position stand: physical activity and bone health. Med. Sci. Sports Exerc., 36(11):1985-96, 2004.

Lazic, M. \& Spasojevic, G. Znacaj kvantitativne ultrazvucne osteodenzitometrije u ranom otkrivanju osteoporoze. Biomedicinska Istrazivanja, 3(2):18-25, 2012.

Martyn-St James, M. \& Carroll, S. Meta-analysis of walking for preservation of bone mineral density in postmenopausal women. Bone, 43(3):521-31, 2008. 
McKay, H. A.; Petit, M. A.; Schutz, R. W.; Prior, J. C.; Barr, S. I. \& Khan, K. M. Augmented trochanteric bone mineral density after modified physical education classes: a randomized schoolbased exercise intervention study in prepubescent and early pubescent children. J. Pediatr., 136(2):156-62, 2000.

Muir, J. M.; Ye, C.; Bhandari, M.; Adachi, J. D. \& Thabane, L. The effect of regular physical activity on bone mineral density in post-menopausal women aged 75 and over: a retrospective analysis from the Canadian multicentre osteoporosis study. BMC Musculoskelet. Disord., 14:253, 2013.

Rasic, P. M. \& Tasic, I. Association between hypertension and osteoporosis in postmenopausal woman. Acta Med. Median., 48(2):8-13, 2009.

Ross, W. D. \& Marfell-Jones, M. J. Kinanthropometry. In: Mac Dougall, J. D.; Wenger, H. A. \& Green, H. J. (Eds.). Physiological testing of the high performance athlete. Champaign, Human Kinetics, 1991.

Schencke, C. \& del Sol, M. Morphologic Changes of the Regeneration in the Rat's (Sprague Dawley) Calnaeous Tendon by Continous Ultrasound Applications. Int. J. Morphol., 28(2):601-8, 2010.

Singh, J. A.; Schmitz, K. H. \& Petit, M. A. Effect of resistance exercise on bone mineral density in premenopausal women. Joint Bone Spine, 76(3):273-80, 2009.

Vainionpää, A.; Korpelainen, R.; Leppäluoto, J. \& Jämsä, T. Effects of high-impact exercise on bone mineral density: a randomized controlled trial in premenopausal women. Osteoporos. Int., 16(2):191-7, 2005.

Wehbe, J.; Cortbaoui, C.; Chidiac, R. M.; Nehme, A.; Melki, R.; Bedran, F.; Atallah, P.; Cooper, C.; Hadji, P. \& Maalouf, G. Age-associated changes in quantitative ultrasonometry (QUS) of the os calcis in Lebanese women-assessment of a Lebanese reference population. J. Musculoskelet. Neuronal Interact., 3(3):232-9, 2003.

Yanagimoto, Y.; Oshida, Y. \& Sato, Y. Effects of walking on bone quality as determined by ultrasound in the elderly. Scand. J. Med. Sci. Sports, 10(2):103-8, 2000.

\section{Correspondence to: Pedro Jesús Ruiz-Montero \\ Departamento de Educación Física y Deportiva \\ Universidad de Granada, España \\ Carretera de Alfacar s/n \\ CP 18001 Granada \\ ESPAÑA}

Email: pedrorumo@ugr.es

Received: 21-02-2015

Accepted: 08-09-2015 